FILOZOFIA

Roč. 76, 2021, č. 1

DOI: https://doi.org/10.31577/filozofia.2021.76.1.3

\title{
GOODMAN A GOMBRICH O POVAHE OBRAZOVEJ REPREZENTÁCIE A REALIZME ZOBRAZENIA
}

JÁN HRKÚT, Katolícka univerzita v Ružomberku, Filozofická fakulta, Katedra filozofie, Ružomberok, SR

HRKÚT, J.: Goodman and Gombrich on the Nature of Pictorial Representation and Pictorial Realism

FILOZOFIA, 76, 2021, No 1, pp. $31-45$

The aim of the paper is to examine the criteria of realism applied to pictorial representations by Ernst Gombrich and Nelson Goodman. In the 2nd half of the 20 th century, they both developed theories as to why some artefactual depictions seem more realistic to us than the others. In both approaches, there is a rejection of classical mimetic doctrine (there is a brief introduction to modern mimetic theory represented by Catherine Abell) as well as a criterion of visual illusion. What makes Gombrich and Goodman different is the assessment of informativeness criterion. While it is sufficient for Gombrich, Goodman goes even further in his relativization. Goodman also rejects informational content as the criterion of realism. The final criterion in Goodman's conception is based on the so-called inculcation. The paper examines the persuasiveness of Goodman's and Gombrich's arguments and mentions the current discussion (Mitrovic, Margolis, Briscoe) on them.

Keywords: Depiction - Pictorial representation - Goodman - Gombrich - Relativity Mimesis - Realism

\section{Úvod}

V umení sa bežne stretávame so zobrazením. Socha Augusta Rodina Myslitel' zobrazuje sediaceho muža, ktorý si podopiera bradu (tá socha muža má zobrazovat' niekoho z trojice Dante Alighieri, Victor Hugo či Charles Baudelaire). Portrét královnej Alžbety II. od Luciana Freuda však bezpochyby zobrazuje Alžbetu Alexandru Máriu Windsor, ktorá je král'ovnou Spojeného král'ovstva od roku 1952. Ale niektoré umelecké diela, či dokonca žánre, nie sú zobrazeniami. Mnohí filozofi umenia sa nazdávajú, že hudba nezobrazuje, ale sa skôr spája s konotáciami. Tiež sa vynára otázka, čo zobrazuje gotická katedrála alebo budova Opery v Syndey, ak vôbec niečo zobrazuje. Otázka o umeleckom zobrazovaní sa však najzrejmejšie týka výtvarných umení. Čo to však znamená, že dielo zobrazuje nejakú vec alebo nejakého človeka? A čo sú to vlastne obrazové reprezentácie? 
Obrazové reprezentácie sú také artefakty, ktoré predstavujú oku diváka 2D statický objekt, pričom zámerom ich tvorcu je evokovat', vyvolat' a simulovat' zobrazenie, ktoré bude rozpoznané ako zobrazenie niekoho alebo niečoho. Obrazové reprezentácie reprezentujú, zastupujú realitu do takej miery, aby divák vnímal, chápal a uznal hodnotu ${ }^{1}$ zobrazenia ako reprezentácie reality. Existujú rôzne typy zobrazení, pričom každé zobrazenie (obraz) môže u divákov vyvolat' množstvo rozmanitých duševných stavov. Filozofov v tradícii angloamerickej estetiky, ktorí sa venujú problematike vnímania a videnia (napr. Briscoe 2018), však osobitne zaujímajú tie zobrazenia, ktoré vyvolávajú zážitok z híbky a 3D štruktúry.

Prečo vznikajú obrazové reprezentácie? Pretože majú schopnost' sprítomnit' divákovi situáciu za istým účelom. Účelom môže byt' umelecké vyjadrenie umelca, predstava budúcej veci (model, návrh), marketingová alebo politická kampaň motivujúca niečo urobit' alebo neurobit', zachytenie spomienky zo zakúšanej udalosti (portrét) a iné. Pokročilé technológie digitálneho zobrazovania, rovnako ako staré portréty alebo mal'by s rozpoznatel'nými objektmi, sú len variantom starej otázky: odkial' vieme, že to, čo je na obraze, naozaj reprezentuje to, čo je zobrazené (to, čo vidí divák, čo rozozná a pomenuje)? Nemám tu na mysli prípady ako abstraktná či nonfigurálna mal'ba. Otázka mieri na tie zobrazenia, ktoré niečo intencionálne zobrazujú (autorova intencia) a divák bez väčších problémov identifikuje tento zámer a mentálne si sprítomní zobrazovaný objekt alebo prostredie.

Ako si teda vytvárame význam obrazu, ak v umení vnímame niečo zobrazené alebo reprezentované? „Obrazy sú objekty určené k vnímaniu. Výzvou pre teóriu obrazového zobrazenia je nájst' správnu teóriu vnímania“ (Rollins 1999, 410). Vo filozofii umenia povahu obrazových reprezentácií vysvetl'ujú tri typy teórií zobrazenia: mimetické, konvencionalistické a psychologické (porov. Hyman, Bantinaki 2017). Po ich rekonštrukcii (pars pro toto prístup cez typických autorov: Catharine Abell, Nelson Goodman, Ernst Gombrich) predstavím otázku o kritériách realizmu. Ide o pálčivú otázku, čo odlišuje viac a menej realistické zobrazenia. Ked’že v tejto oblasti ponúkli dve dominantné odpovede Gombrich a Goodman, porovnám ich prístupy a zhodnotím presvedčivost' ich teórií s prihliadnutím na niektoré súčasné komentáre a interpretácie.

\section{Mimetické teórie zobrazenia}

Od najstarších gréckych teórií umenia v západnej filozofii dominoval explanačný princíp fundovaný kategóriou mimesis (mimêsis). Táto kategória je dobre vyjadrená ako

\footnotetext{
${ }^{1}$ Hodnota zobrazení môže byt’ rôzna: epistemická, psychologická, sociálna, umelecká a pod.
} 
napodobňovanie. Ide o napodobňovací princíp reprezentácie, teda opätovného sprítomnenia niečoho, čo (už) nie je pre naše zmysly bezprostredne prítomné. U Platóna nachádzame v X. knihe Ústavy opakovane vysvetl'ovanú umeleckú činnost' ako aktivitu napodobňovania (porov. Platón 2003, 593 b, c; 598 a, c). Je dobre známe, že Platón podrobil umeleckú napodobňovaciu činnost' intenzívnej epistemologickej a morálnej kritike. Podl'a Platóna umelec z dôvodu nedostatku pravdivosti vytvára zlé veci. A ešte $\mathrm{k}$ tomu svojou činnost'ou ovplyvňuje tú najhoršiu čast' našej duše (porov. Platón 2003, 605 b). Je zaujímavé, že Platón identifikoval kl'účový explanačný princíp umenia, ten, ktorý $\mathrm{v}$ teórii umenia následne dominoval dlhšie ako dve tisícročia, ale zároveň ho hodnotil vel'mi negatívne, až tak, že navrhuje umelcov vyhostit' zo svojho ideálneho štátu. Niederle to priliehavo zdôvodňuje Platónovou požiadavkou na spoločenskú užitočnost' umenia (porov. Niederle 2010, 82).

Ovel'a ústretovejšie sa na mimesis princíp pozerá Aristoteles v diele Poetika. Ked' vysvetl'uje, ako vzniká umenie, uvádza: „Poézia epická a tragická, d'alej komédia a poézia dityrambická a väčšina hry na píštale a na kitare, všetky vznikajú v podstate napodobňovaním“ (Aristoteles 1980, I, 1., 16). ${ }^{2}$ Táto klasická mimetická teória dominovala vysvetleniam umenia až do neskorého novoveku. V rôznych podobách ju ešte aj v devätnástom storočí obhajujú filozofi ako Charles Sanders Peirce alebo John Ruskin. Ruskin je romantický filozof prírody, ktorý pokladá napodobňovanie prírody za najvyšší estetický princíp. Inšpirácia prírodou má u Ruskina dokonca dvojakú povahu: na nižšej úrovni ide o priame napodobnenie konkrétnych prírodných tvarov, na vyššej úrovni umelec preberá abstraktný zdroj krásy vo forme kriviek a členenia (porov. Stibral 2011,70). Mimetická teória sa stáva menej presvedčivou aj pod vplyvom nástupu umeleckých avantgárd začiatkom dvadsiateho storočia. Tie kladú dôležitú otázku o úlohe napodobňovania, vzhl'adu, tvaru a farby v umení.

K mimetickým princípom teórie obrazových reprezentácií sa v súčasnosti aj zoči-voči ostrej kritike Goodmana a Gombricha prihlásilo niekol'ko autorov, ktorí navrhli úpravu tejto stratégie. Jedna z popredných predstaviteliek tohto typu teórie, oxfordská profesorka Abellová navrhla, aby sa pri vysvetl'ovaní obrazových reprezentácií prihliadalo na dve kritériá: informatívnost' a relevanciu. Čím sú obrazy realistickejšie, tým relevantnejšie sú informácie, ktoré poskytujú o vzhl'ade ich objektov. To, nakol'ko realistický je obraz pre danú komunitu, bude závisiet' od toho, aké relevantné sú informácie, ktoré poskytuje o vzhl'ade objektu pre danú komunitu (porov. Abell 2006). Obe tieto kritériá vychádzajú z mimetickej stratégie. Samozrejme, v dôsledkoch to znamená, že kritérium realizmu sa bude nachádzat' v podobnosti s reálnymi

\footnotetext{
${ }^{2}$ Aristoteles d'alej vysvetl'uje, že napodobňovanie je vrodená schopnost' (Aristoteles I, 4., 6) a dvojakým spôsobom človeku spôsobuje radost' (Aristoteles I, 4., 10), a síce samo napodobňovanie, ale aj sledovanie napodobnenín.
} 
objektmi, ktoré sú zobrazované, reprezentované. „Štýl zobrazenia je realistický do tej miery, do akej obrazy v tomto štýle môžu realisticky zobrazovat širokú škálu bežných typov objektov“ (Abell 2007, 14). Vzt’ah k tvarom a farbám robia zo zobrazení relevantné zdroje informácií. Nie to, ako umelci transformujú zobrazené veci, ani to, akými psychologickými postupmi vzbudzujú asociácie s reálnymi objektmi sveta. Abellová a moderní proponenti mimetickej stratégie vzt'ahujú obrazové zobrazenia k vlastnostiam objektov, ktoré diváci rozpoznávajú aj v realite, vo svojom bežnom živote a skúsenostiach.

Rozličné varianty teórie inšpirovanej mimetickým princípom zjednocuje klúčová myšlienka: diela zobrazujú alebo reprezentujú objekty takým spôsobom, že sa na ne (alebo na ich klúčové vlastnosti) podobajú.

\section{Konvencionalistické teórie zobrazenia}

Vo svete umenia mnohé umelecké diela reprezentujú a zobrazujú, a pritom ani na prvý pohl'ad nemožno povedat', že prostredníctvom podobnosti. Ak sa pozrieme na spomínaný portrét Královná Alžbeta II., jeden detail na obraze vyjadruje to, že je král'ovná. Je to královská koruna na jej hlave. Bez toho, aby Lucian Freud musel opisovat' a vymenúvat' územia, v ktorých panuje, vieme, že král'ovská koruna na hlave znamená najvyšši post (bez ohl’adu na to, či formálny alebo výkonný) v Spojenom královstve. Teda král'ovská koruna na hlave staršej dámy neznamená len ozdobu, nereprezentuje len šperk, ale reprezentuje (zobrazuje) jej titul a spoločenské postavenie. Koruna na hlave a význam jej zobrazenia pre oko diváka už netkvie v podobnosti, ale v konvencii, vd’aka ktorej rozoznávame symbol (znak) panovníka.

Existujú však obrazové reprezentácie, ktoré ani ako celok nemožno vysvetlit' pomocou princípu podobnosti. Georges Braque namal'oval niekol'ko plátien, ktoré nazval Domy v L'Estaque. Tieto mal'by z prvej dekády dvadsiateho storočia sú považované za jasné príklady takzvaného analytického kubizmu. Keby sme sa pýtali, čo zobrazujú, odpovede by mohli byt' legitímne rôzne. Poznajúc životný príbeh autora vieme, že Braque sa v roku 1908 zdržiaval v južnom Francúzsku, kúsok od mesta Marseille v oblasti, ktorá sa volá L’Estaque. No ešte dôležitejším poznatkom je štýl, ktorým v tom čase Braque mal'oval. Na základe toho vieme, že viacero jeho obrazov $\mathrm{z}$ tohto obdobia zobrazuje obydlia v meste a na vidieku v okolí L'Estaque. Keby sme to nevedeli, mohli by sme si mysliet', že na obrazoch sú zobrazené kúsky tekvice pomiešané so šalátom, alebo iné hranaté žlté predmety s listami či konárikmi. Keby sme aplikovali vyššie uvedené Abellovej kritériá - informatívnost' a relevanciu -, tieto obrazy by boli vzhl'adom na to, čo reprezentujú (ak reprezentujú domy), málo informatívne a len v prenesenom zmysle relevantné. No predsa zobrazujú domy v okolí L'Estaque. Akou teóriou to možno vysvetlit? Teória napodobňovania to nie je. 
Jednou z možností je použit' teóriu Goodmana, ktorá je typom konvencionalistickej, alebo inak povedané symbolickej teórie. ${ }^{3}$ Goodman v tejto teórii tvrdí, že základný vzt'ah medzi zobrazením a objektom, ktorý je zobrazený, nie je podobnost', ale referencia. „Ak má obraz nejaký objekt zobrazovat', musí ho označovat', zastupovat', odkazovat' $\mathrm{k}$ nemu, a žiadna miera podobnosti nestačí pre ustanovenie požadovaného vzt'ahu referencie" (Goodman 2007, 22). Obrazy teda nie sú reprezentáciami niečoho, pretože sa na to niečo podobajú, ale preto, že na to niečo odkazujú. Referencia je podl'a Goodmana primitívny, d’alej neanalyzovatel'ný vzt’ah medzi referentom a jeho zobrazením. A čo je mimoriadne dôležité, tento vzt'ah nemá väzby k tvaru, farbe alebo štruktúre objektov, ktoré sú zobrazené, ale stojí na konvencii, symbolizácii, ktorú ako diváci akceptujeme alebo neakceptujeme, pričom obrazová reprezentácia sa nám vtedy neprihovára, pre nás nereprezentuje danú autorskú intenciu.

„Ak je obsah zobrazenia skutočne založený na tejto [Goodmanovej - pozn. J. H.] teórii percepcie, potom vzt'ahy obrazu a objektu nebudú l'ubovol'né; [...] A hoci konvencionalista Goodmanovho typu môže súhlasit's tým, že sa naučíme rozpoznávat' vzt’ahy obrazu a objektu v súlade s niektorými psychologickými zákonmi, z toho nevyplýva, že vzt’ahy sú pre neho dané týmito zákonmi. Naopak, fakty l’udskej psychológie sú pre takéhoto konvencionalistu nedôležité, pretože tieto fakty môžu znamenat' aj niečo úplne iné; a preto jeho formálna logická analýza systémov symbolov zostáva nedotknutá“ (Rollins 1999, 390). Konvenčná povaha identifikácie symbolov je odlišná od psychologickej kauzality (ktorú uvidíme v Gombrichovej teórii). U Goodmana sú dôležité zdiel’ané symbolické významy, ktoré nie sú podmienené psychologickými regularitami (zákonitost’ami l'udského vnímania a preživania), ale kultúrnou gramotnost’ou. Symboly sú zdiel'ané dynamické významy, kódované v systéme kultúrnych objektov (textov, obrazov, objektov) a kultúrnej pamäte istej skupiny l'udí.

Ako Goodman zdôvodňuje to, že obrazové reprezentácie sú predovšetkým a najmä referenciami (nie imitáciami či ilúziami objektov)? V prvom rade ide o to, že objekty, ktoré sú zobrazované, nám nie sú dané samozrejme a bez problémov v totalite a celistvosti toho, čím a ako sú (porov. Hrkút 2012, 56). Goodmanovými slovami: ,... nič nemožno zobrazit' bez vlastností ani so všetkými vlastnost'ami. Obraz nikdy X len nezobrazuje, ale zobrazuje $\mathrm{X}$ ako muža či zobrazuje $\mathrm{X}$ tak, aby vyzeralo ako hora alebo zobrazuje fakt, že X je melón. Čo by mohlo znamenat' ,napodobnenie faktu', by bolo tažké pochopit', aj keby niečo ako fakty existovalo“ (Goodman 2007, 25). Pre Goodmana teda zobrazovanie objektov v umení nie je v žiadnom prípade vytváraním ich kópií či napodobnenín. ,Je zrejmé, že existuje vel’a objektov, ktoré sú v určitých

${ }^{3}$ Zaradit' Goodmanovu teóriu medzi konvencionalistické je štandardná klasifikácia (porov. Hyman, Bantinaki 2017). Vychádza z toho, že Goodman chápe povahu reprezentácie ako konvenčnú (porov. Zeleňák 2013, 375). 
ohl'adoch vel'mi podobné znázornenému objektu, ale zvyčajne sa nepokladajú za reprezentácie tohto objektu ([v prípade obrazu zobrazujúceho strom čerešňu - pozn. J. H.] napr. iné čerešne alebo dokonca iné stromy pripomínajú danú čerešňu väčšmi ako mal'ba čerešne). Preto podobnost' nie je dostatočnou podmienkou“ (Zeleňák 2013, 374).

Obrazovým reprezentáciám a procesu ich zobrazenia lepšie porozumieme, ak ich budeme chápat' ako proces selekcie istých vlastností a triedenia objektov. Pred každým obrazom si podl'a Goodmana môžeme položit' dve otázky: 1) čo zobrazuje (či opisuje) a 2) o aký druh obrazu (či opisu) ide. Prvou sa pýtame, na ktoré objekty sa obraz vzt'ahuje. Druhou, ktoré z možných označení sa vzt'ahujú na obraz. Tým, že obraz niečo zobrazí, vyčlení nejakú triedu predmetov a vlastností a do nejakej triedy obrazov sa sám zaradí (porov. Goodman 2007, 40). Sumárne možno povedat', že konvencionalistické teórie (vrátane Goodmanovej) považujú obrazové reprezentácie za denotácie ${ }^{4}$ a vzt'ahy medzi reprezentovaným a reprezentujúcim sú arbitrárne a konvenčné.

\section{Psychologické teórie zobrazenia}

Psychologický typ teórie zobrazenia predstavím cez vybraného autora, ktorým je Gombrich. Jeden z míl'nikov príbehu jeho teórie je ukotvený v roku 1956, ked' ho nadácia Andrewa. Williama Mellona pozvala predniest' prestižnu prednášku A. W. Mellon Lectures in the Fine Arts. Gombricha pozvali ako odborníka na výtvarné a vizuálne umenie. O štyri roky neskôr publikoval prednášky pod názvom Umenie a ilúzia: štúdia psychológie obrazovej reprezentácie (Gombrich 1960/1984). Aj vd’aka tomuto dielu Gombricha pokladajú za jedného z najvýznamnejších historikov a teoretikov výtvarného umenia dvadsiateho storočia. ${ }^{5}$ Jeho Umenie a ilúzia sa zvyčajne označuje za prelomový text v chápaní moderného výtvarného umenia. Gombrichov výskumný projekt je rozsiahly a tu nie je priestor venovat' sa väčšine jeho analýz vývoja umeleckých diel. Bez ambície pokryt' celý vplyv tejto práce uvediem niektoré, pre špecifickú teóriu obrazového znázornenia dôležité tvrdenia.

Obrazové zobrazenie v umeleckých dielach je ich základným stavebným prvkom. Diela niečo reprezentujú, odkazujú na niečo mimo seba, vonku, mimo obrazu. Toto je prirodzená, intuitívna a nekontroverzná téza. Avšak spýtajme sa: Na čo odkazujú obrazy? Na svet, na predmety, l'udí, postavy, veci, možno aj na charakteristiky a vzt'ahy vo svete. Ako to vieme? Na obrazoch (umeleckých dielach) zrejme spoznávame niečo zo sveta. Chápeme, že zobrazené odkazuje na zobrazované. V renesančnej

\footnotetext{
${ }^{4}$ Denotáciu chápem ako vzt'ah medzi označením a tým, čo sa označuje. Pre Goodmana je denotácia (popri exemplifikácii) jednou z dvoch základných foriem referencie (Goodman 2007, 55 - 59).

${ }^{5} \mathrm{~V}$ češtine bolo Gombrichovo kl'účové dielo vydané takmer o dve desatročia neskôr (Gombrich 1985). Medzi Goodmanom a Gombrichom sa odohrávala diskusia aj priamo, pozri Gombrich (1972) a Goodman (1960a).
} 
mal'be a klasickej perspektíve sa nám môžu veci javit' jasné. Namal'ovaný muž na obraze Portrét manželov Arnolfini (1434) od Jana van Eycka reprezentuje (označuje) talianskeho bankára Giovanni di Arrigo Arnolfini. Namal'ované zrkadlo za touto postavou predstavuje zrkadlo ako skutočný objekt na stene jeho domu v Bruggách. A tak by sme mohli pokračovat'. Ak však opustíme „klasický“ obraz a začneme si klást' rovnaké otázky pri impresionistických obrazoch (o 450 rokov mladších), a najmä v neskoršej tvorbe avantgardného či abstraktného umenia, odpovede nebudú také jednoznačné. Napriek náročnosti interpretácie nemáme dôvod pochybovat', že aj tieto diela niečo reprezentujú, to znamená, že odkazujú na niečo mimo seba (zobrazenie), na niečo mimo obrazu, na objekty, ktoré môžeme opísat' mimo sféry umenia. Ako to však vieme? Najprv vyskúšajme analogickú otázku, ktorú kladie Gombrich, ked' sa pýta na klasicky iluzívne zobrazenie, teda na obraz s viacerými významami. Vo svojej knihe Umenie a ilúzia, ale s najväčšou pravdepodobnost'ou aj na vyššie spomenutých prednáškach, predstavil svojmu publiku tento obrázok: ${ }^{6}$

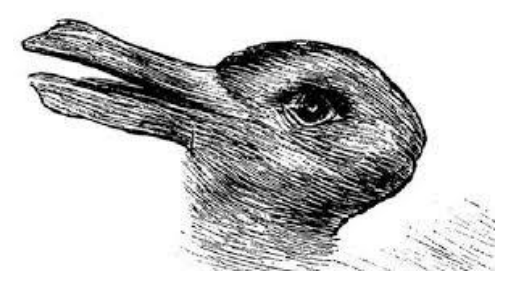

Prečo tento obrázok? Zvyčajne sa to v literatúre označuje ako kačica-králik obraz. Základný výklad je založený na otázke, či vidíte kačicu alebo králika. Zrejme naraz neuvidíte obe zvieratá, ale iba jedno. Rozvetvený tvar na lavej strane je zobák (kačice) alebo uši (králika). „Tento príklad ukazuje inherentnú dvojznačnost' všetkých zobrazení a rovnako nám pripomína dôvody, prečo si ich len zriedkakedy uvedomujeme. Dvojznačnost' [...] nemožno nikdy vidiet'. Spozorujeme ju len vtedy, ked' sa naučíme prepnút' z jedného čítania na druhé a ked' si uvedomujeme, že obe interpretácie znázornenia sú rovnako výstižné“ (Gombrich 1985, 291). Rovnako výstižné znamená, že nie sú v hierarchii, obe sú správne a obe sú vyjadreniami toho, čo daný obraz reprezentuje.

\footnotetext{
${ }^{6}$ Obrázok nie je Gombrichovým výtvorom. Táto ilustrácia bola prvýkrát publikovaná 23. 10. 1892 v nemeckom humoristickom časopise Fliegende Blätter v článku s názvom Welche Thiere gleichen einander am meisten? (Ktoré zviera je najviac podobné inému zvierat'u) s podtitulom Kaninchen und Ente (Králik a kačica). Prvýkrát ho v akademickom svete použil americký psychológ Joseph Jastrow. K pôvodu a významu tohto zobrazenia pozri McManus $(2010,167)$.
} 
Analogickým príkladom, ale v abstraktnejšom prevedení, je takzvaná Neckerova kocka (NC):

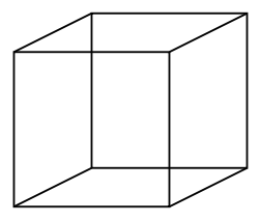

$\mathrm{NC}$

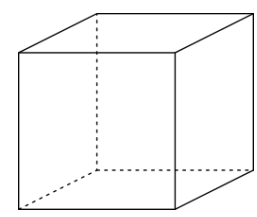

int. 1

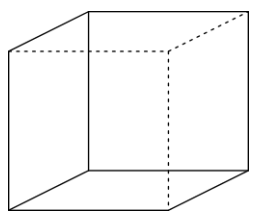

int. 2

V zobrazení NC sa nám ponúkajú dve možnosti interpretácie. Pri tomto type ambiguitného obrázka sa vždy sústredíme len na jednu interpretáciu (int. 1 alebo int. 2), na jeden uhol pohl'adu. Neckerovu kocku môžeme vnímat' zdola alebo zhora, a tým v mysli konštruujeme dve odlišné usporiadania. Náš pohl'ad sa musí vysporiadat's konvertovaním dvojpriestorového zobrazenia na trojpriestorové. NC zobrazenie (hoci je geometricky chybné), dobre ilustruje Gombrichovo ${ }^{7}$ tvrdenie, ktoré by sa dalo vyjadrit’: vnímanie obrazových reprezentácií vopred závisí od teórie alebo predporozumenia. Nie interpretácia, ale samo vnímanie, rozlíšenie obsahu obrazu nie je možné bez istých (podla Gombricha najmä psychologických) predpokladov.

Tieto viacznačné zobrazenia nás chcú naučit', že to, čo vidíme pred sebou, je zmesou toho, čo vidíme, ako to vidíme a ako k tomu pristupujeme. Pretože pri interpretácii viacvýznamových zobrazení hrajú dôležitú úlohu fillozofické a psychologické aspekty a východiská. „Pri čítaní obrazov, rovnako ako pri počúvaní hovoreného slova, je vždy t’ažké rozlíšit' to, čo je nám dané, od toho, čo dopĺńame v priebehu procesu projekcie, ktorý sa k poznaniu pohotovo pripoji““ (Gombrich 1985, 283). Nachádzajú sa v umeleckých dielach zobrazenia, ktoré možno interpretovat' vo viacerých významoch? Bezpochyby. Umelecké diela nie sú zrkadlá (porov. Gombrich 1960/1984, 5). Obrazové zobrazenia nie sú vytvárané ako verné obrazy. Je ich zámerom napodobnit', zobrazit', reprezentovat' objekt, napríklad človeka takého, aký je v skutočnosti? Zobrazený objekt je predsa „človekom, ktorého mám pred sebou, je to človek, zhluk atómov, komplex buniek, priatel', pijan, a nielen to" (Goodman 2007, 23) - pomohol by Gombrichovej argumentácii Goodman. A keby sme to aplikovali na kresbu kačicakrálik, čo vidíme? Kačku, králika, kožušinové zviera, operené zviera, hlavu so zobákom, hlavu cicavca? Gombrich a Goodman sa pri kritike mimetickej (napodobňova-

\footnotetext{
${ }^{7}$ Gombrich neuvádza Neckerovu kocku ako prípad ambiguitného zobrazenia. No nazdávam sa, že ho dobre vystihuje a je príkladom Gombrichovej teórie.
} 
cej) teórie zhodujú dokonca aj v tom, že reprezentácie v umeleckých dielach nepokladajú za nositel’ov stabilných významov. Obaja sú v tomto zmysle relativisti, pretože tvrdia, že význam obrazovým reprezentáciám neprisudzujeme primárne podl'a toho, aké objekty sú reprezentované, ale podl'a našich konvenčných alebo psychologických štruktúr. Inak povedané, sémantika obrazových reprezentácií je fundovaná niečím iným ako objektom zobrazenia.

To, čo Gombrich priniesol a vyt’ažil z výskumu psychológie umenia, sú tvrdenia, ktoré nás dnes už prekvapujú menej ako jeho súčasníkov v šest'desiatych rokoch dvadsiateho storočia. Posolstvom je opatrnost' pri jasnom alebo jednoznačnom výklade obrazových reprezentácií. Na jednom mieste Gombrich spomína dokonca potrebu pokory pri interpretácii vizuálnych zobrazení (porov. Gombrich: 1960/1984, 291). V čom je teda jadro Gombrichovej (psychologickej) teórie? Podl'a neho naše interpretácie obrazových zobrazení závisia do istej miery od toho, čo by sme mohli nazvat' paradigma. ${ }^{8}$. „Mentálne obsahy nemožno nikdy identifikovat' izolovane, ale iba ako súčast' vzájomne prepojenej siete duševných stavov. Táto vzájomná závislost' schém, konceptov a presvedčení je zrejmá z Gombrichovej teórie, ked' hovorí o tendencii našej mysle klasifikovat' a registrovat' naše skúsenosti v zmysle známeho na jednej strane; a vplyvu, ktorý majú získané vzory alebo schémy na organizáciu nášho vnímania na druhej strane“ (Rollins 1999, 399). Vzhl’adom na tlak očakávaní, potrieb a kultúrnych návykov reagujeme odlišne. Všetky tieto faktory môžu mat' vplyv na predbežné nastavenie zámky, ale nie na jej odomknutie, čo stále závisí od otočenia pravého klúča (Gombrich 1960/1984, 289 - 290).

Bez nadinterpretácie možno hovorit', že tu ide o istý druh relativizmu. Táto relativita vo vnímaní umeleckých diel je dokonca charakteristická, no nielen po interpretačnej stránke. Gombrich pokladá reprezentáciu v umení za základnú činnost' na oboch stranách: umelca i recipienta. To, čo skúmame v umení, je povaha videnia a reprezentácie, problém prepojenia objektivity a konvencie reprezentácie, objektivity a relativity videnia v umení. Podl'a Gombricha by bolo vel'mi naivné mysliet' si, že obrazové znázornenie prírody alebo l'udí sa odvíja najmä od tvarov prírodných predmetov a vlastností tváre niekoho (teda kritizuje mimetické teórie). Schopnost' vykreslit' a interpretovat' artefakty závisí najmä od koncepčných schém (porov. Gombrich 1960/1984, 289 - 290). Tieto mentálne súbory či predpoklady, ktoré predchádzajú obrazovej reprezentácii, sú dnes ešte zretel’nejšie na základe súčasných výskumov a empiricky potvrdzujú Gombrichove intuície pred polstoročím. ${ }^{9}$

\footnotetext{
${ }^{8}$ Termín paradigma tu nemá odkazovat' na význam, v akom ho používal Thomas Samuel Kuhn, ale vyjadruje sa ním epistemická či mentálna množina. Ide o rámec, ktorý nevyhnutne použivame, ked’ klasifikujeme alebo poznávame.

${ }^{9}$ Zaujímavý výskum robí v tejto oblasti Robert Briscoe z University of Ohio (Briscoe 2016; 2018).
} 
Gombrich trvá na tom, že v umeleckom stvárnení „neexistuje realita bez interpretácie; žiadne nevinné oko, žiadne nevinné ucho“ (Gombrich 1960/1984, 291). Je to bezpochyby reakcia na slabnúci vplyv mimetických teórií (napr. Ruskina). Ruskin, anglický kritik umenia z druhej polovice devätnásteho storočia, požadoval pri interpretácii umenia nevinné oko. Mal tým na mysli objektivitu a nestrannost' recipienta, pretože tieto podmienky považoval za objektívne a nevyhnutné pre umeleckú kritiku. Ideál tohto typu nestranného hodnotenia umeleckých diel má aj d’alšie korene v estetike Davida Humea a Imanuela Kanta. „Historici vedy tvrdia, že asi v polovici devätnásteho storočia sa vo viacerých vedeckých odboroch vytvoril ideál ,skúseného oka', ktorý nahradil predchádzajúci ideál mechanickej objektivity“ (Kesner 2009/2010, 42). Ideál nestranného hodnotenia sa potom $\mathrm{v}$ dvadsiatom storočí radikálne zmenil a dnes už len t’ažko nájdeme filozofa, ktorý by pri interpretácii umeleckých diel bránil nevinné oko.

Podl'a Gombricha je typickou vlastnost'ou ,živých organizmov spájat', [...] hádat', predpokladat' druh alebo typ prichádzajúceho stimulu, testovat' a transformovat' očakávania, a testovat' znova. Nevinné oko je mýtus“ (Gombrich 1960/1984, 239). Teória nevinného oka ${ }^{10}$ je potom naivným prístupom $\mathrm{k}$ uchopovaniu vizuálnych obrazov. „Skutočný zázrak oka spočíva práve v rýchlosti a istote, s ktorými interpretuje interakciu nekonečne vel'kého počtu kl'účov“ (Gombrich 1985, 316). Podl'a Margolisa „Gombrich nikdy netvrdil, že existuje nejaký jedinečne alebo nezávisle prirodzený spôsob, ako reprezentovat' prírodu“ (Margolis 2004, 219). Gombrich to odmieta ako nesprávnu alternatívu. Na opísanie vizuálneho sveta skutočne nepotrebujeme iba oči, ale aj rozvinutý jazykový systém schém a gramatiky videnia. „Bez východiskového bodu, počiatočnej schémy, by sme nikdy nemohli využit’ tok skúseností. Bez kategórií by sme svoje dojmy nemohli triedit' “ (Gombrich 1960/1984, 71). Opät' by sme tu mohli vidiet' istú paralelu s Goodmanom, ktorý proces interpretácie obrazových reprezentácií tiež opisuje v kategóriách triedenia a klasifikácie istých objektov a ich vlastností (porov. Goodman 2007, 40).

Gombrich nás teda učí, že vnímanie umeleckého zobrazenia znamená použitie schém a ich okamžitú korekciu, a neskôr opät' korekciu, úpravu nášho videnia a znova korekciu. „Ked’ zdôrazňujem vylučovanie nesprávnych dohadov a metódu pokusu a omylu pri každom získavaní vedomostí [...] postupujem ako K. R. Popper (Gombrich 1985, 317). Jednoducho bez schémy obrazové reprezentácie nemôžeme ani vnímat'. „Každá vizuálna percepcia je závislá od konceptuálnej reprezentácie“ (Mitrovic 2010, 2). Scheme and correction sú kl'účové pojmy Gombrichovej teórie obrazovej

10 „Ten Ruskinov slepec, ktorý zrazu uvidí, nevidí svet ako obraz Turnera alebo Moneta - dokonca aj Berkeley vedel, že môže zažit' iba chytl'avý chaos, ktorý sa musí naučit' zorganizovat' [...] Lebo vidiet' nikdy nie je iba evidovat"“ (Gombrich 1960/1984, 239). 
reprezentácie. Schéma je však vel’mi dynamická a jej kategórie podliehajú ustavičnej korekcii a úpravám. „To si bezpochyby vyžaduje tvorivost' a odhodlanie podstúpit' navrhovanie a testovanie ,hypotéz' ${ }^{6}$ - skúšanie pohl'adov, čo zahíňa nielen pohyb $\mathrm{v}$ priestore, ale najmä pohyb v mojej mysli. Ak budem mat' dostatok vytrvalosti, budem odmenený skúsenost’ou, ktorú by som v prvom prípade nenadobudol“ (Šedík 2018, $654-655)$.

Ako som už spomenul vyššie, Gombrich predpokladá tento proces uplatňovania predpokladov, mentálnych schém, na príjemcu aj umelca. „Platón proti takejto zmene namietal. To, čo môže umelec vytvorit' [...] je len fenomén; je to svet ilúzií, svet zrkadiel, ktoré oklamú oko ... Ale ako imitátor tohto meniaceho sa zmyslového sveta nás vzd'aluje od pravdy a musí byt' zo štátu vylúčený“ (Gombrich 1960/1984, 93). Umelci sa učia reprezentovat' a vizualizovat' vonkajší svet učením sa od predchádzajúcich umelcov. To potom vysvetl'uje určitú stereotypnú tendenciu a charakter tvorivých umeleckých postupov, zobrazení, prejavov, jednoducho spôsob, akým umelci odkazujú na svet.

Reprezentácia teda nie je iba reprodukciou sveta, aký je sám osebe, alebo ako je správne videný, reprezentácia nikdy nie je duplikátom či napodobnením. Na rozdiel od Platóna si Gombrich nemyslí, že umelec vytvára kópie, tiene, zrkadlové obrazy sveta. Umelci skôr vytvárajú kompozície, konglomeráty predchádzajúcich schém, skúseností, predpokladov, postupov, ktoré zažili a zapamätali si, a impulzov, ktoré sú pred nimi. Ked' Jan van Eyck prostredníctvom portrétu reprezentuje Arnolfini, jeho tvorba je tvorivou kombináciou toho, čo sa malo reprezentovat', a toho, kto bol ako maliar, čo zažil, čo vedel reprodukovat' a od čoho sa pri svojom štýle nevedel odpútat'. Rozdiely v štýle umelcov nemožno vysvetlit' rozdielmi v ich videní ani manuálnymi zručnost’ami; pretože to, čo vo svojich dielach reprezentujú, závisí od schém, v ktorých vidia veci. Stále je príliš zjednodušené povedat', že umelec reprodukuje skôr to, čo vie, ako to, čo vidí. Obraz je plochý a statický, zato svet, ktorý reprezentuje, je viacrozmerný a dynamický, svet v pohybe a zmene. Farby na obrazoch sú ovel’a jednoduchšie a menej pestré ako rozmanité farby, ktoré môžeme vo svete pozorovat'. Preto, ak sa nám obraz prihovára, predstavuje to odkaz na svet vo vizuálnom umení, určite nie duplicitu, opakovanie a reprodukciu skutočného sveta. Odkaz alebo referencia, to je elementárny vzt’ah obrazu a objektu, ktorý sa vo výtvarnom umení nevyskytuje priamo, ale vo vizuálnom jazyku. A vývoj takého jazyka je dlhý a zložitý proces, ktorý popisuje históriu konkrétnych umeleckých žánrov.

Psychologické teórie obrazovej reprezentácie sú charakteristické tvrdením, že „každé znázornenie je výzvou pre vizuálnu predstavivost'; musí byt' doplnené, aby mu 
bolo porozumené“ (Gombrich 1985, 283). A zvyčajne ho dopíňa reakcia diváka, recipienta, pretože „bez divákovej aktívnej spoluúčasti zostávajú umelecké diela nemé a inertné" (Kesner 2009/2010, 53).

\section{Gombrich a Goodman o kritériách realizmu}

Gombrich tvrdí, že umenie referuje k realite, dokonca vytvára obraz reality, ale nie je jednoduchou napodobneninou. Nejde pri ňom ani o ilúziu, ktorej ciel'om by bola zámena umenia a reality, ale o reprezentáciu reality tak, aby bola realita $\mathrm{v}$ obraze rozpoznaná. „Žiadne zobrazenie nám nemôže znázornit’ viac než určité aspekty svojho prototypu. Ak by to tak nebolo, bol by to dvojník" (Gombrich 1985, 283). My si nikdy obraz s realitou nepomýlime. Umenie pracuje s obrazom, ktorý reprezentuje realitu, ale nie na spôsob doslovnej presnosti. Dá sa povedat', že táto reprezentácia má analogickú funkciu a povahu ako jazykové vyjadrenie opisujúce nejakú realitu.

Pre Gombricha je vytvorenie obrazu reprezentujúceho realitu vysvetlitel'né psychologicky, a to konkrétne prostredníctvom kategórie substitúcie. „Gombrich zhromaždil nepreberné množstvo príkladov, aby ukázal, ako rozdielne môžu byt' spôsoby nahliadania a zobrazovania $\mathrm{v}$ závislosti na skúsenostiach, cviku, záujmoch a postojoch“ (Goodman 2007, 25 - 26). Gombrich teda zdôrazňuje psychologicky podmienenú konvenciu ${ }^{11}$ a v prípade umeleckých reprezentácií špecifické umelecko-psychologické konvencie. Ako teda podl'a Gombricha rozpoznáme viac či menej realistické zobrazenia? „Percepčné rozpoznávanie závisí od zosúladenia vizuálneho stimulu so známymi formami, ktoré sa časom upravujú, ak je zosúladenie opakovane príliš nepresné. Aj ked' Gombrich pokladá schémy za vymyslené obrazové techniky, jednoznačne sú založené na psychologických mechanizmoch. Proces párovania a korekcie odráža princíp adaptovania stereotypu, ktorý vyjadruje, že schémy sú ako prototypy vnímania; nie prísne pravidlá alebo definície pre klasifikáciu objektov, ale prekrývajúce sa množiny funkcií, ktoré poskytujú kritériá na posudzovanie stupňov podobnosti medzi členmi triedy“ (Rollins 1999, 398). Gombrichovým kritériom sú teda známe formy poznania a reprezentácie, o ktoré sa opiera náš proces tvorby schém a ich korekcie.

„Napríklad obraz neznámeho zvierat’a alebo neznámej budovy nám nepovie nič o jej rozmeroch, ak nám nejaký známy predmet nedovolí odhadnút mierku“ (Gombrich 1985, 283). A samozrejme, tým predmetom musí byt' niečo, čo sme už v predchádzajúcej skúsenosti rozpoznali a porovnali s inými, predtým spoznanými predmetmi. Realistické zobrazenie je akoby ret’azovo prepojené s množstvom skúseností a vnemov,

${ }^{11}$ Táto konvencia je odlišná od Goodmanovej. Gombrichova konvencia je bližšia tomu, čo jeho komentátori nazývajú kolektívne paradigmy (Mitrovic 2010,6) alebo aj formy kolektívnej percepcie (Mitrovic 2010, 7). Na inom mieste Mitrovic popisuje tieto Gombrichove psychologické predpoklady ako konštanty (Mitrovic 2013, 81). 
ktoré sme predtým uznali za realistické. „Aby sme zopakovali Filostratovo tvrdenie ,nikto nemôže pochopit' namal'ovaného koňa alebo býka, ak nevie, ako také stvorenia vyzerajú'. Chyba, ktorá tol'kokrát zaviedla teoretizovanie o umení na scestie, spočíva v domnienke, že musia existovat' nejaké prostriedky, ktorými sa dá znázornit',podoba', alebo dokonca ,priestor' ako taký“" (Gombrich 1985, 291). Túto pozíciu môžeme nazvat' relativistickou, pretože predpokladá možnost' väzby na ,realitu' len prostredníctvom iných reprezentácií, zret’azenia predchádzajúcich hodnotení ako realistických. Briscoe nazýva tento aspekt Gombrichovej teórie hypotéza kontinuity. Myslí tým skutočnost', že obrazy majú silu vyvolat' v nás vizuálnu skúsenost' takého druhu, ktorý poznáme zo stretnutí s realitou (porov. Briscoe 2018, 50) A práve to by mohlo byt' presvedčivou odpoved'ou Gombricha na otázku, ktoré obrazové reprezentácie sú realistickejšie. Sú to tie reprezentácie, ktoré lepšie zachovávajú kontinuitu medzi vnímaním reality mimo zobrazení a v zobrazeniach (obrazových reprezentáciách).

Naproti tomu Goodman, hoci s Gombrichom súhlasí ohl'adom kritiky reprezentácií ako napodobnenín, považuje referencie za kultúrne podmienené vzt’ahy. Podl’a Goodmana je videnie, a ešte väčšmi zobrazovanie, relatívne (porov. Goodman 2007, 25). „Realizmus je relatívny, určený systémom zobrazenia, ktorý je pre danú kultúru či osobu v danej dobe štandardný“ (Goodman 2007, 44). Vytvorenie obrazu reprezentujúceho realitu Goodman vysvetl'uje ako schopnost' symbolicky vyjadrit' a komunikovat' rozpoznatel'né črty pre istú kultúrnu komunitu.

Otázku o povahe realistického zobrazenia si Goodman kladie vel'mi jasne. V ôsmej časti prvej kapitoly svojej knihy Jazyky umenia najprv vyvracia možné alternatívy toho, v čom by mohla tkviet' realistickost' zobrazenia. Odmieta imitáciu (mimesis), ilúziu, ale aj kritérium, ktoré neskôr prijala Abellová (porov. Abell 2007) a síce relevanciu informácií, ktoré nám zobrazenie poskytuje o reprezentovanom svete. „Nejde o množstvo informácií, ale o to, ako l'ahko sa nám vybavia. To však závisí na tom, nakol'ko stereotypný je spôsob zobrazenia, ako bežnými sa stali označenia a ich používanie“ (Goodman 2007, 43 - 44). Stereotypy, inak povedané štandardy, však nie sú fixné a nemenné; k zmenám toho, čo považujeme za štandardné zobrazenie, dochádza.

Goodman nás pravdepodobne ,učí tomu, že pri každom (aj tom najrealistickejšom) obraze použivame interpretačné nástroje a pravidlá, ktoré sú nevyhnutné, aby sme obrazu rozumeli [...] Realistickost' prisudzujeme tým zobrazeniam, ku ktorým máme interpretačný kl'úč už v kapse“ (Hrkút 2012, 60). Toto používanie schém, ich aplikácia a následná korekcia môže pripomínat' Gombrichovu teóriu. Rozdiel medzi nimi je však v tom, že Goodman pokladá realizmus obrazových zobrazení za vec zvyku (porov. Goodman 2007, 45), zatial’ čo Gombrich zrejme verí, že realizmus má predsa len vzt'ah $\mathrm{k}$ svetu mimo zobrazenia, a to vo forme kontinuity, prítomnosti is- 
tých vlastností vo svete aj v reprezentácii sveta. Goodmana preto považujem za relativistu v silnejšom zmysle slova, pretože obhajuje pozíciu, že to, čím popisujeme a zobrazujeme svet, nemožno overit' vzhl'adom na vonkajší svet (porov. Goodman, Elginová 2017, 178), ale vždy len vzhl'adom na štandardy, ktoré sme konvenčne prijali. Realizmus nemôže byt' záležitost'ou vernosti prírode a nemožno ho merat' podobnost'ou s realitou, pretože naše úsudky o vernosti prírode závisia od našich vizuálnych návykov, ktoré sú zase formované vizuálnou kultúrou, ktorú obývame, a obrazmi, ktoré sme zvyknutí vidiet' a interpretovat' (porov. Hyman, Bantinaki 2017).

\section{Záver}

Uvedené teórie predstavujú filozofické vysvetlenia charakteru a podmienok obrazových reprezentácií. Mimetická teória prirodzene formuluje stabilnú väzbu medzi reprezentáciu a tým (objekty sveta), čo je reprezentované. Tento vzt’ah je opisovaný ako podobnost' a vnímajúci subjekt, divák môže túto podobnost' objavit', pričom ju sám nekonštruuje. Teórie Gombricha aj Goodmana tendujú k relativistickému vysvetl'ovaniu povahy obrazových reprezentácií. Gombrich smeruje k relativizmu na základe psychologizujúcich podmienok a epistemickej procedúre tvorby schém a ich korekcií, ktorá smeruje $\mathrm{k}$ podmienenosti interpretácie obrazov voči vnímajúcemu subjektu. Goodman považuje napodobňovanie, iluzívnost' aj relevantné informácie za arbitrárne vlastnosti obrazových reprezentácií a za také ich aj považuje. Gomrichova aj Goodmanova teória sú preto relativistické. Goodmanova relativita vizuálneho vnímania smeruje aj k odmietnutiu každého iného vysvetlenia realistickej reprezentácie ako toho, na ktoré sme zvyknutí, ktoré pokladáme za štandardné a známe.

\section{Literatúra}

ABELL, C. (2006): Realism and the Riddle of Style. Contemporary Aesthetics, 4 (4).

ABELL, C. (2007): Pictorial realism. Australasian Journal of Philosophy, 85 (1), 1 - 17. DOI: https://doi.org/10.1080/00048400601185529

ARISTOTELES (1980): Poetika. Rétorika. Politika. Bratislava: Tatran.

BRISCOE, R. (2016): Depiction, Pictorial Experience, and Vision Science. Philosophical Topics. 44 (2), 43 - 81. DOI: https://doi.org/10.5840/philtopics201644217

BRISCOE, R. (2018): Gombrich and the Duck-Rabbit. In: Beaney, M. - Harrington, B. - Shaw, D. (eds.): Aspect Perception after Wittgenstein: Seeing-As and Novelty. New York: Routledge, $49-88$.

GOMBRICH, E. (1960/1984): Art and Illusion: A Study in the Psychology of Pictorial Representation. London: Phaidon \& Princeton University Press.

GOMBRICH, E. (1972): The 'What' and the 'How': Perspective Representation and the Phenomenal World. In: Rudner, R. - Scheffler, I. (eds.): Logic and Art: Essays in Honor of Nelson Goodman. Indianapolis \& New York: Bobbs-Merrill, 129 - 149.

GOMBRICH, E. (1985): Umění a iluze. Studie o psychologii obrazového znázorňování. Praha: Odeon. 
GOODMAN, N. (1960a): Art and Illusion: a Study in the Psychology of Pictorial Representation / Gombrich, E. H. (Review). The Journal of Philosophy, 57 (18), 595 - 599. DOI: https://doi.org/10.2307/2023612

GOODMAN, N. (1960b): The Way the World Is. The Review of Metaphysics, 14 (1), 48 - 56. DOI: revmetaph1960141116

GOODMAN, N. (2007): Jazyky umění. Nástin teorie symbolů. Praha: Academia.

GOODMAN, N., ELGINOVÁ, Z. C. (2017): Nové pojetí filozofie a dalších uměni a věd. Praha: Univerzita Karlova.

HRKÚT, J. (2012): Nelson Goodman a otázka realizmu. Filosofický časopis, 60 (1), 55 - 64.

HYMAN, J., BANTINAKI, K. (2017): Depiction In: Zalta, E. N. (ed.): The Stanford Encyclopedia of Philosophy.. Dostupné na: https://plato.stanford.edu/archives/sum2017/entries/depiction/ (Navštívené: 16. 9. 2020).

KESNER, L. (2009/2010): Podíl diváka. Pokus o oživení Gombrichova pojmu. In: Gombrich. Porozumět uměni a jeho dějinám. Brno: Barrister \& Principal, MUNI Press.

MARGOLIS, J. (2004): The Philosophy of Visual Arts: Perceiving Paintings. In: Kivy, P. (ed.): The Blackwell Guide to Aesthetics. Oxford: Blackwell Publishing, 215 - 229.

McMANUS, I. C. et al. (2010): Science in the Making: Right Hand, Left Hand. II: The duck-rabbit figure. Laterality, $15(1-2), 166-185$.

MITROVIC, B. (2010): A Defence of Light: Ernst Gombrich, the Innocent Eye and seeing in perspective. Journal of Art Historiography 3.

MITROVIC, B. (2013): Visuality After Gombrich: The Innocence of the Eye and Modern Research in the Philosophy and Psychology of Perception. Zeitschrift Für Kunstgeschichte, 76, 71 - 89.

NIEDERLE, R. (2010): Pojmy estetiky: analytický prístup. Brno: Masarykova univerzita.

PLATÓN (2003): Ústava. Platónovy spisy. Svazek IV. Praha: Oikoymenh.

ROLLINS, M. (1999): Pictorial representation: When cognitive science meets aesthetics. Philosophical Psychology, 12 (4), 387 - 413. DOI: https://doi.org/10.1080/095150899105657

STIBRAL, K. (2011): Estetika a př́roda v díle Johna Ruskina. In: John Ruskin a príroda. Brno: Muni Press, $62-98$.

ŠEDÍK, M. (2018): O povahe poznania v umení. Filozofia, 73 (8), 647 - 659.

ZELEŇÁK, E. (2013) Using Goodman to Explore Historical Representation. Journal of the Philosophy of History, 7 (3), 371 - 395. DOI 10.1163/18722636-12341258

Práca vznikla v rámci projektu VEGA č. 1/0640/19 s názvom Pojmový relativizmus v súčasnej filozofii: vymedzenie, limity a problémy.

\section{Ján Hrkút}

Katolícka univerzita v Ružomberku

Filozofická fakulta, Katedra filozofie

Hrabovská cesta 1B

03401 Ružomberok

Slovenská republika

e-mail: jan.hrkut@ku.sk

ORCID ID: https://orcid.org/0000-0002-5268-1106 